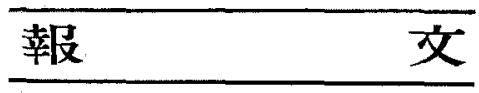

\title{
無撚系織物の引張りにおける初期挙動について
}

\author{
岐阜大学工業短期大学部渡 辺明 \\ 岐阜大学工学部 \\ 黒崎新也・近田富士雄
}

\section{THE BEHAVIOR OF TWISTLESS-YARN FABRIC IN THE INITIAL EXTENSION}

\author{
By Akira Watanabe, * Shinya Kurosaki** and Fujio Kanda** \\ * (Junior Technical College, Gifu University, Kakamigahara City, Gifu Prefecture, Japan) \\ ** (Faculty of Engineering, Gifu University, Kakamigahara City, Gifu Prefecture, Japan)
}

\begin{abstract}
Recently, the twistless yarns and their fabrics have been developed. In previous paper, it was shown that the rupture forces of the twistless yarn fabrics were as same as those of the conventional twist yarn fabrics. The considerations were based upon the compressive forces working at the intersecting points of the yarns in the fabrics and inter-fiber frictional forces which increase with tension.

In this paper, the initial extensional properties of the twistless yarn fabrics $\left(T_{0} F\right)$ and the twist yarn fabrics $\left(\mathrm{T}_{2.6} \mathrm{~F}\right)$ are comparatively discussed, concerning the changes of yarn cross-section shapes and sizes (Fig. 8), yarn packing factors (Fig. 9) and yarn crimp angles (Fig. 10) during extension. The aspects of the fabric crosssections are shown in Fig. 7. The various factors of equation (7) are obtained by above experimental results. (Table 2) Fig. 12, the initial regions of load-elongation curves both twistless and twist yarn fabric, are calculated from the equation (7). The calculated and experimental results are compared in Fig. 13. The difference between the twistless and twist yarn fabrics are remarkably characterized by the aspects of initial regions of loadelongation curves. That seems to depend on the differences of mobility of fibers in both fabrics.
\end{abstract}

(Received March 17, 1975)

\section{1. 緒言}

近年，無然系括よび無然系織物が新しく開発されてい る。Tex-Ja系，T.N. O. 系などの製法とその織物の特 性について, R.D.Wells ${ }^{1)}$, J.W. Powischill ${ }^{2)}$, H. J. Selling ${ }^{3)}$, P. R. Load"らが報告している.われ わ扎は，前報 ${ }^{5)}$ に执いて，無然系自身はほとんど強力を もたないが，その織物は引張りによって，系と系の交錯 点に側王力が発生し，絨維間祭擦力が增加するため，従 来の撚系織物と同程度の破壊強力を示すことを理論的に 考察し，実験結果との一致を示した。

織物の初期伸長特性は，しわ回復，生䨂特性，曲げ特 性などと同様に，実用的見地からみて，きわめて重要な 特性であり，織物權造に関連した基本的な問題の1つで
ある。無撚系織物の初期伸長特性を研究することはこ の立場から意義あることと思われる。

従来, 䅧物の初期伸長特性に関寸る研究は，数多く報 告されている ${ }^{6 \sim 10\rangle}$.これらの論文に㧍いて，系を匤縮さ れない弾性体として取扱っている研究が多く，初期の荷 重一伸長曲線は，主として織物中の糸のクリンプ角の変 化によって決定されるとしている。従来の織物恃，加撚 系からできており，引張りの初期においては，織物中の 系のハッッキング染，断面形状などの集合性の時間的変化 は，ほとんどないと考えられる。しかし，無然系織物で は、引張りによって織物中の瀻維が大きく移陲するため， 従来の考えちに，さらに系構造の变形你存性を考愿する 必要がある。

本報は，無然系織物の初期の引張りにともなう系のハ 
ッキング率，糸の断面形状括よび寸法，苏のクリンプ角 などの時間的変化を追跡し，従来の撚系織物との違いを 丰験的に明らかにした。またこれらの因子をとにし て, 無撚系織物の初期の荷重一伸長曲線を理詥的に考察 し、燃莱䄉物と比較檢討した。

\section{2. 試料および害験方法}

\section{1 試 料}

a）米：原料は繊維長 $51 \mathrm{~mm}$ (等長)，繊度 $2 \mathrm{~d}$ のピス コースレーヨンで, 粗紡機あがりの粗系 (1.5 番手)を用 いた。無然系は前報と同様に図 1 の無撚系作成装㞸によ り紡續した。糊材は，5\% P.V.A.溶液で，付着㐁は5 7 ஜである。紡出番手は，22's である。撚手は従来のり

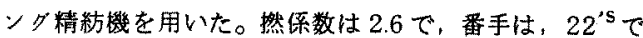
ある。

また，織物の初期の引張りにともなう棏造の変形依存 性を詳紐に観察するために，1.5's の無撚系と撚婇数 2.6 の撚糸を紡續した。

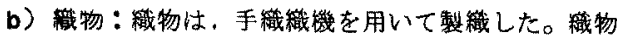
中の系密度を表 1 （a）に示与，経系密度，繶系密度の代

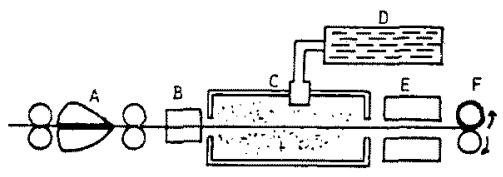

Fig. 1 Apparatus for the production of twistless yarn.
A : Drafting part
B : Convergenter
C : Sprayer
D : $5 \%$ P.V.A. Solution
E : Dryer
F : Twistless yarn

わりに，織物の引腲り方向の采密度，引張りに直交する 系密度で表わした。22 s の系の無撚糸織物を $\mathrm{T}_{0} \mathrm{~F}$ ，それ に対応する撚系織物を $\mathrm{T}_{26} \mathrm{~F}$ で表わす。

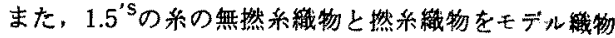

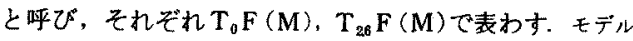
織物の糸密度を表 I（b）に示す。

撚系織物は製織の際，P. V. A.を释糸糊材として用い た。製織後，無撚系織物，撚系織物がともに同じ条件に なるように，50Cの温水でP. V. A.の糊抜きを行ない。 標準状態に調湿した。

\section{2 実験方法}

22 番手の米の織物 $\left(\mathrm{T}_{0} \mathrm{~F}, \mathrm{~T}_{28} \mathrm{~F}\right)$ と， 1.5 番手の糸の モデル織物 $\left(\mathrm{T}_{0} \mathrm{~F}(\mathrm{M}), \mathrm{T}_{26} \mathrm{~F}(\mathrm{M})\right)$ の引張り試験を、イ ンストロン型テンサイルテスターで行なった。試料の大 きさは，試長 $10 \mathrm{~cm}$, 幅 $5 \mathrm{~cm}$ で，引張り速度は $20 \mathrm{~mm} /$ minである。

22 番手の系の無撚系織物(No. 1 No. 3) と, 然系織 物 (No. 4 No. 6) を, Diacotton Rhoduline Red B で染色し，標隼状態に調湿したのち，固定㓮(パラフィ ン,エチルセルロース、ステフリン酸を $2: 1: 10$ 割合 で溶解したもの)で固めた。そのたて方向，よこ方向の 断面を顕澈鏡で観察し，写真をとった。

綱物を引張ることによって、織物中の系がどのような 举動を示すか，また断面形状がいかに変化するかを，乇 デル織物（No.7ーNo. 12）を用いて，詳細に険討した。 Diacotton Rhoduline Red Bで染色したもデル䇝物 を， $0 \% ， 5 \% ， 10 \% ， 15 \% ， 20 \%$ ，切断前の各伸度 まで引張り，その状態のまま鉄製の㭝で織物を把持し， さらに固定剂を流して織物を固定した。各試料の中央に おけるたて方向よこ方向の断面を，力セトィーターで観 察し，写真をとった。その写真より，系の形態，系の中 心の位置，系のクリンブ角，系の長径および短径などの

Table 1 Yarn density of the fabric.

\begin{tabular}{|c|c|c|c|c|c|}
\hline & \multicolumn{2}{|c|}{$\begin{array}{l}\text { Sample } \\
\text { number }\end{array}$} & $\begin{array}{l}\text { Yarn } \\
\text { count } \\
\text { ('S) }\end{array}$ & $\begin{array}{l}\text { Yarn density in the } \\
\text { tensile direction } \\
(\mathrm{N} / \mathrm{cm})\end{array}$ & $\begin{array}{l}\text { Yarn density in the } \\
\text { normal direction to } \\
\text { tensile }(\mathrm{N} / \mathrm{cm})\end{array}$ \\
\hline \multirow[b]{2}{*}{ (a) } & $\mathrm{T}_{0} \mathrm{~F}$ & $\mathrm{~T}_{2.6} \mathrm{~F}$ & & & \\
\hline & $\begin{array}{l}\text { No. } 1 \\
\text { No. } 2 \\
\text { No. } 3 \\
\end{array}$ & $\begin{array}{l}\text { No. } 4 \\
\text { No. } 5 \\
\text { No. } 6\end{array}$ & $\begin{array}{l}22 \\
22 \\
22 \\
\end{array}$ & $\begin{array}{l}21 \\
21 \\
21 \\
\end{array}$ & $\begin{array}{l}17 \\
25 \\
30\end{array}$ \\
\hline \multirow[b]{2}{*}{ (b) } & $\mathrm{T}_{0} \mathrm{~F}(\mathrm{M})$ & $\mathrm{T}_{2.6} \mathrm{~F}(\mathrm{M})$ & & & \\
\hline & $\begin{array}{l}\text { No. } 7 \\
\text { No. } 8 \\
\text { No. } 9\end{array}$ & $\begin{array}{l}\text { No. } 10 \\
\text { No. } 11 \\
\text { No. } 12\end{array}$ & $\begin{array}{l}1.5 \\
1.5 \\
1.5\end{array}$ & $\begin{array}{l}4.3 \\
4.3 \\
4.3\end{array}$ & $\begin{array}{l}2 \\
3 \\
4\end{array}$ \\
\hline
\end{tabular}

$\mathrm{T}_{0} \quad \mathrm{~F}$ : twistless yarn fabric

$\mathrm{T}_{2.6} \mathrm{~F}$ : twist yarn fabric with 2.6 twist factor

$\mathrm{T}_{0} \mathrm{~F}(\mathrm{M})$ : twistless yam fabric (model)

$\mathrm{T}_{2.6} \mathrm{~F}(\mathrm{M})$ : twist yarn fabric (model)
因子について測定した。

\section{3. 実験結果および考察}

\section{1 結 果}

22 番手の系の無撚系織物 と然系織物の荷重一伸長曲線 を图 2 に示す。同じ系密度の $\mathrm{T}_{0} \mathrm{~F}$ と $\mathrm{T}_{26} \mathrm{~F}$ を比較すると， 引張りの初期に扔いては，同 一伸度にお打る荷重が $\mathrm{T}_{0} \mathrm{~F}$ よ りも $\mathrm{T}_{26} \mathrm{~F}$ の方が大きい。と ころが，5〜10\%の伸度で， その傾向が逆転し， $\mathrm{T}_{28} \mathrm{~F}$ の 方が小さくなっている。 
無撚系織物之撚系織物の断面写真の1 例を図 3 に示す。 試料は, No. $2\left(\mathrm{~T}_{0} \mathrm{~F}\right)$ と No. $5\left(\mathrm{~T}_{26} \mathrm{~F}\right)$ である。これよ り無然系織物中の系の断面は, 目の形”)をして, 紻維が 平行に配列しているのが見られる。一方，撚采織物中の 系の断面は, 棈円形で, 㵶維泣ラセン状に配列し、系が しまっている。このように，無撚系織物と撚系織物では， 系の形態, 系のクリンプ角, 繊維の配列, 系のパッキン グ率などの構造因子の值が大きく異なっている。これら の構造因子は，織物の荷重 - 伸長曲線の初期の部分に大 きな影譬をあたえ，これらの因子が引張りによって,ど
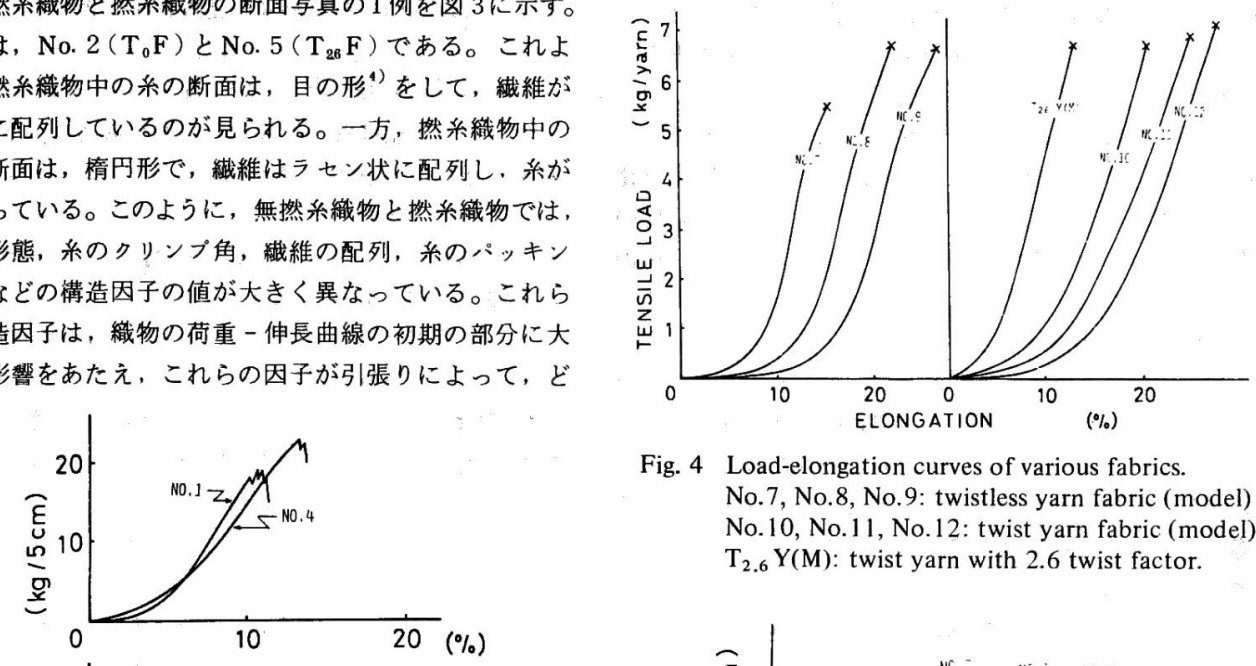

Fig. 4 Load-elongation curves of various fabrics. No.7, No.8, No.9: twistless yarn fabric (model) No. 10, No.11, No.12: twist yarn fabric (model) $\mathrm{T}_{2.6} \mathrm{Y}(\mathrm{M})$ : twist yarn with 2.6 twist factor.
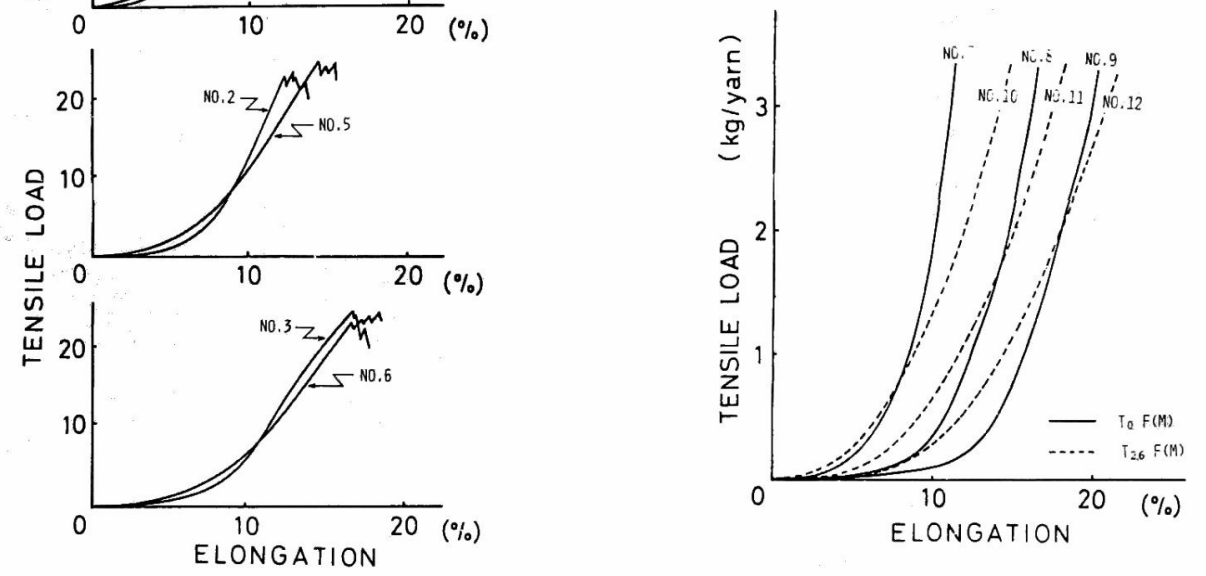

Fig. 2 Load-elongation curves of various fabrics. (No. 1, No. 2, No. 3: twistless yarn fabrics, No. 4 , No. 5 , No. 6 : twist yarn fabrics with 2.6 twist factor.)

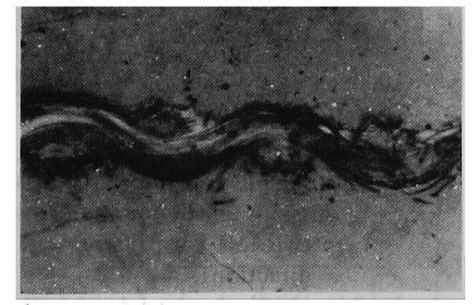

(a)

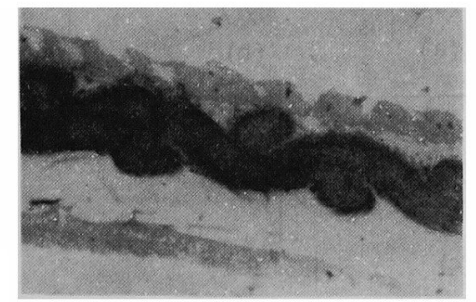

(b)

Fig. 3 Microphotographs of the yarn cross-sections of the fabric. ( $\times 50)$

(a) twistless yarn fabric. ( $T_{0} F$, No. 2)

(b) twist yarn fabric. $\left(T_{2.6} F\right.$, No. 5) 
のように時間的に変化するかがわかれば，無撚系糡物と 撚糸織物の荷重一伸長曲線の違いが, 理解できるものと 思われる。

モデル鐵物 $\left(\mathrm{T}_{0} \mathrm{~F}(\mathrm{M}), \mathrm{T}_{26} \mathrm{~F}(\mathrm{M})\right)$ ) 各試料の荷重 伸長曲線を図 4 に示す。これらの曲線の初期の部分を比 較すると, 図 5 のようになる。これより, 同一密度の $T_{0} F(M) と T_{26} F(M)$ につて，前述の 22 番手の系の 織物と同様の傾向を有している。

\section{2 考 察}

a）理論的考察：従来、織物の初期の荷重 - 伸長曲線 について, 織物構造因子のうちで糸のクリンプ角が，そ の様相を大きく左右する因子として取扱われている ${ }^{6 \sim 10)}$ 。 しかし，実際に織物の引張りにともなう織物中の系の状 態の変形依存性を詳細に追跡し，その結果を導入して解 析した研究はほとんどない。われわれは，つぎのように 織物の初期の荷重一伸長曲線について考察し, 無撚系織 物と撚系織物を比較検討した。

図 6 (a) は, 無張力時の織物中の系の形態である。図 6 (b) は, 織物の引張り過程のある伸度における禾の形 態で, 引張り方向にそって切断した場合である。引張り 方向の釆の中心線を折れ線に近似させ, 図 6 (c) (d)の ように符号をつける $(X:$ 織物中の糸の交錯点における 引張り方向の糸とそれに直交する系の中心間距離， $Y$ : 引張り方向の系を折れ線に近似させたときの 1 単位長, $Z$ : 引張り方向に直交する系の中心間距離, $\theta:$ 引張り 方向の系のクリンプ角)。

織物の伸度を $\varepsilon_{F}$, 織物中の采の伸度を $\varepsilon_{Y}$, 織物の系 1 本あたりの張力を $F_{F}$, 織物中の釆の張力を $F_{Y}$ とする。

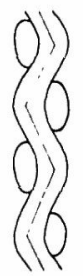

(a)

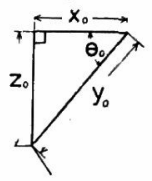

(c)

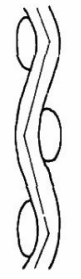

(b)

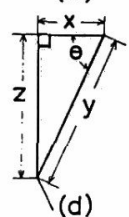

Fig. 6 Yarn cross-sections of the fabric.

(a) without tensile forces.

(b) with tensile forces. (cutting along the tensile)

(c) (d) lengthes and their changes of unit cell elements.
$\varepsilon_{F}, \varepsilon_{Y}$ は，それぞれつぎのように表わされる。

$\varepsilon_{F}=Z / Z_{0}-1$

$\varepsilon_{Y}=\sqrt{Z^{2}+X^{2}} / \sqrt{Z_{0}^{2}+X_{0}^{2}}-1$

また， $X$ の変化は織物の与えられた伸度に比例すると仮 定すると, (3) 式が成り立つ。

$$
X=X_{0}-a \varepsilon_{F}
$$

(ただし， $\varepsilon_{F} \geqq X_{0} / a$ のとき $X=0$ )

(2) 式に (1) (3) 式を代入する。

$$
\left(Z_{0}^{2}+X_{0}^{2}\right)\left(1+\varepsilon_{Y}\right)^{2}=Z_{0}^{2}\left(1+\varepsilon_{F}\right)^{2}+\left(X_{0}-a \varepsilon_{F}\right)^{2}
$$

(4) 式は, $\varepsilon_{F}$ と $\varepsilon_{Y}$ の関係を示している。ここで, 采の 伸度 $\varepsilon_{Y}$ と張力 $F_{Y}$ の関係を $(5)$ 式のようにおく。

$$
\varepsilon_{Y}=f\left(F_{Y}\right)
$$

また， $F_{F}$ と $F_{Y}$ の関係は $(6)$ 式で表わされる。

$$
F_{F}=F_{Y} \sin \theta
$$

(4) 式に，（5)(6) 式を代入して (7) 式となる。 $\left(Z_{0}^{2}+X_{0}^{2}\right)\left(1+f\left(F_{F} / \sin \theta\right)\right)^{2}=Z_{0}^{2}\left(1+\varepsilon_{F}\right)^{2}+\left(X_{0}-a \varepsilon_{F}\right)^{2}$ ただし, $\sin \theta=Z_{0}\left(1+\varepsilon_{F}\right) / \sqrt{Z_{0}^{2}\left(1+\varepsilon_{F}\right)^{2}+\left(X_{0}-a \varepsilon_{F}\right)^{2}}$

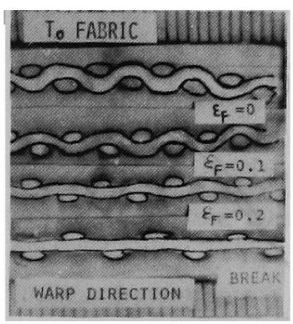

(a)

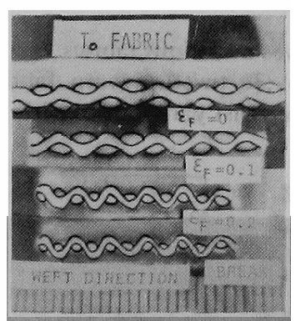

(b)

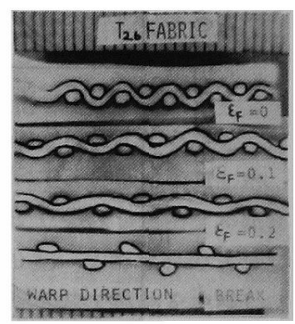

(c)

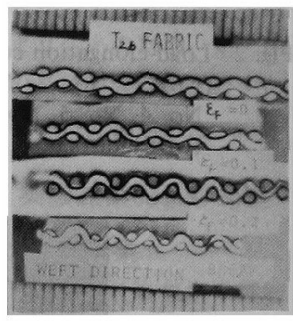

(d)
Fig. 7 Photographs of the yarn cross-sections in the fabric with tensile forces.

(a) twistless yarn fabric. (cut along the tensile direction)

(b) twistless yarn fabric. (cut at the right angle to the tensile direction)

(c) twist yarn fabric. (cut along the tensile direction)

(d) twist yarn fabric. (cut at the right angle to the tensile direction) 
(7) 式は，鐡物の伸度 $\varepsilon_{F}$ と，“儎物の糸1本あたりの張 力F $F_{F}$ 関保を示し， $X_{0} ， Z_{0} ， \theta ， a の$ 各因子の値と, 米 の初期の荷重 - 伸長曲線がわかれば, 織物の初期の荷重 一伸長曲線を得ることができることを示している。

b) 䡴物の桡成因子の時間的变化：織物の引張りにと もなう傤中の米の状態の变化の写真を図 7 に示す。こ 机は，伸度 $0 ， 10 ， 20 \%$ そして切断寸前の伸度のときの 織物の断面写真を順に並べたものである。图 7(a)(b) は，無撚系織物 (No.8)で, (c) (d) は撚系織物(No.11) である。これより；引帪り力向の糸はそのクリンプが伸 ばされて直線化し，同一平面上にのるようになる。一方， 引張り方向に直交する采は，引張り方向の采の側王によ ク押し出され，クリンブ角が增加し、引張り方向の系と の接触面積が增加する。

引張りにともなって变化する糸断面の長径および短径 の測定結果と形状をまとめて図 8 に示寸。(A) は，引張 り方向に直交する番の断面で,（B）は，引張り方向の糸 の断面である。引張り方向に直交する手の断面住偏平化 が生じ，無撚糸の方が撚糸よりその程度が大きい。また， 引張り方向の系の断面は, 然然系撚系とも糸の円形化が 生じ、切断時ではほとんど円に近い形をしている。

つぎに，引張りにともなう織物中の来のパッキング率 の変化を四 9 に示す。糸のハッキンダ率 $(1-\varepsilon)$ は，糸

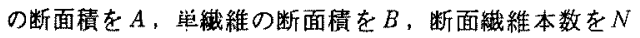
とし, $1-\varepsilon=B N / A(\varepsilon:$ 空隙率)より計算した。

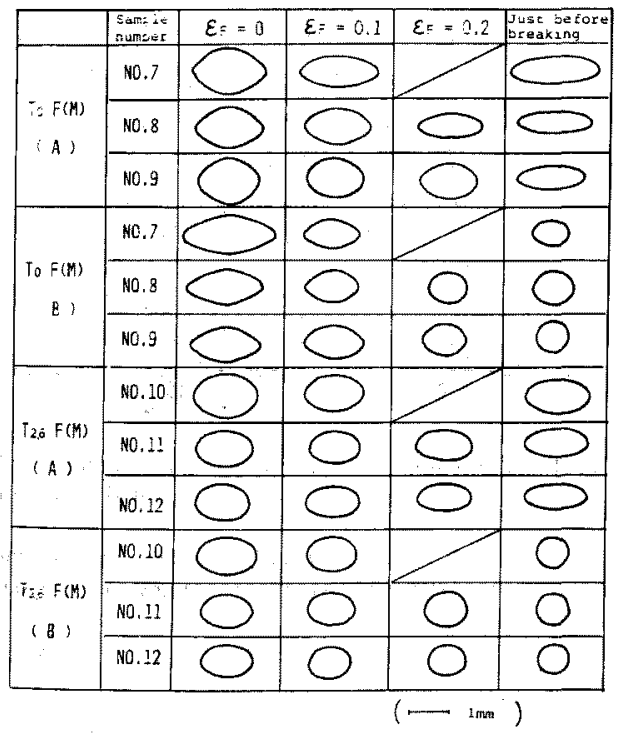

Fig. 8 Changes of shapes and sizes of the yarns. $A$ : the right angle to the tensile direction $B$ : the tensile direction
無張力時において，無然系のパッキング率は6〜8\%で 低い値であるが，撚系は13〜15\%で，然のため高い值 である。引張り方向の杀について，無然糸 (A) は引張り にともなって，パッキング率が急激に增加し，切断時で は25\%近くまで達している。一方，撚系（B）では，ハ ッキング率の增加が少ない。引張り方向に直交する糸の ハッキング率の変化は，無然系 (C)，撚系 (D)ともに小 さく，撚系はほとんど変化していない。この無撚采織物 中の系の顕著なパッキング率の変化は，無撚糸特有のッ フト性と大いに関連がある。

つぎに，引張りにともなう織物中の糸のタリンプ角の 変化を図10に示子。糸のクリンプ角 $(\theta)$ は，つぎのよ

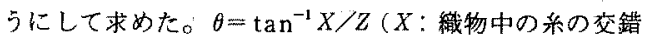
点における引張り方向の系とそれに直交する手の中心間 距離， $Z$ : 引張り方向に直交する糸の中心間距唯）無張 力時に括いては，無然系然系とも同程度のクリンプ角で ある。しかし，引張りにともなって，無然糸の方が然禾 よりクリンプ角の変化の程度が大きく，低い伸度で糸の 直線化が生じている。このクリンブ角の変化は, 荷重一 伸長曲線の初期の部分を決定する重要な因子である。

c）計算值し奏験值の比較：糊を抜いた無然系は，試 長が䋞維長以上のとき，ほとんどすべての瀻維が滑脱す るため、引張り張力はごくわずかである゙,。しかし， その織物の引張り過程に拈ける系の状熊を観察すると， 織物構造の変形にともない采の交錯点での側王力抢よび パッキング率がしだいに增加し，緎維閻摩摖力が大きく

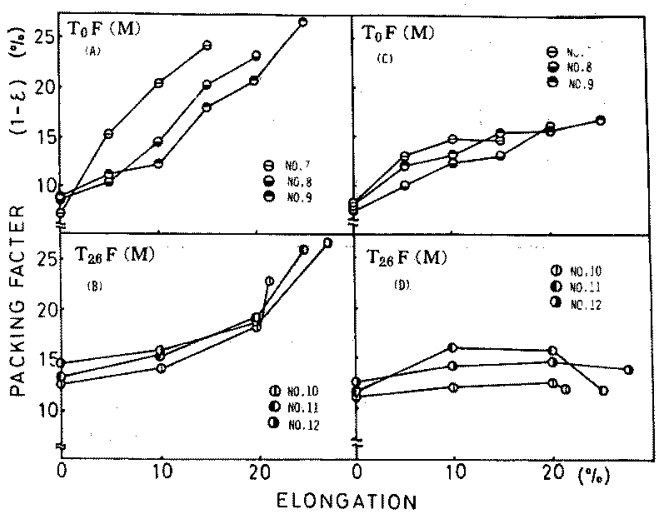

Fig. 9 Changes of the yarn packing factor in the fabric with tensile forces.

(A) twistless yarns. (the tensile direction)

(B) twist yarns. (the tensile direction)

(C) twistless yarns. (the right angle to the tenșile direction)

(D) twist yarns. (the right angle to the tensile direction) 


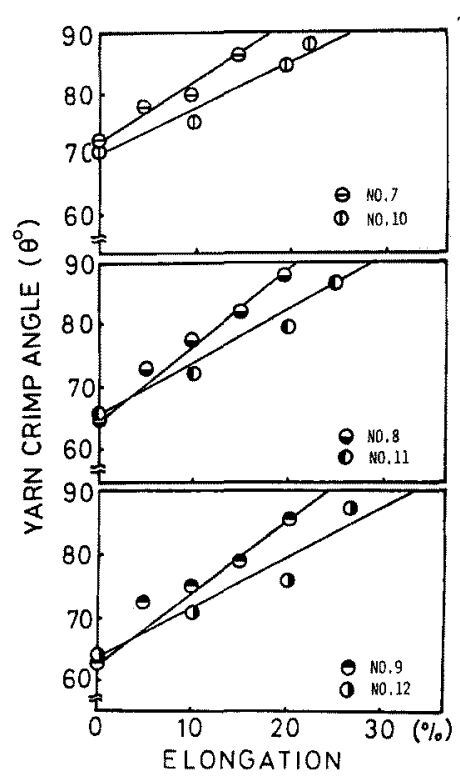

Fig. 10 Changes of the yarn crimp angles of the tensile direction. (No. 7, No. 8, No. 9: twistless yarns, No. 10 , No. 11, No. 12 : twist yarns)

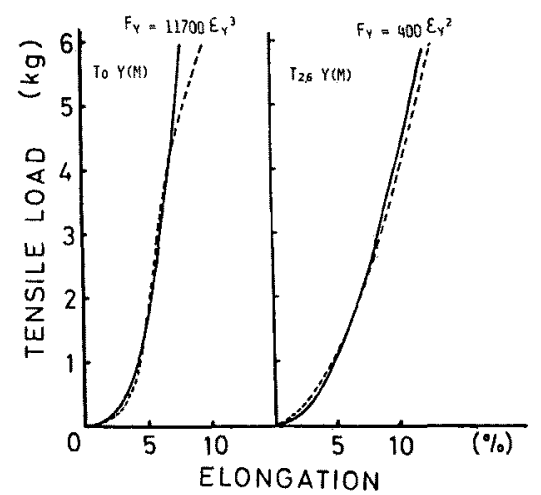

Fig. 11 The initial regions of load-elongation curves. (sample length : $10 \mathrm{~mm}$ )

(right : twist yarn, left : twistless yarn.) (- - :- : experimental, —_ : fitted)

なり、繊維相互の自由な滑脱はほとんどないことがわか る。無然禾とその織物の引張りを対応させると，系中に 括ける㵶維の自由な滑脱が拘束された形，すなわち紼維 長以内の試長における引張り挙動に近似できるものと考 えられる。そこで, 試長 $10 \mathrm{~mm}$, 引張り速度 $20 \mathrm{~mm} / \mathrm{min}$ で杀の引張り試験を行なった。無撚系と撚系の荷重一伸 長曲線を図 11 に示す。曲線の初期の部分の実験式を(8)
The values of various factors obtained by the experimental results.

\begin{tabular}{|c|c|c|c|c|c|c|c|c|c|}
\hline & \begin{tabular}{|l|} 
Sample \\
number
\end{tabular} & $\theta_{0}$ & $\sin \theta_{0}$ & $\begin{array}{c}X_{0} \\
(\mathrm{~mm}) \\
\end{array}$ & $\begin{array}{c}Z_{0} \\
(\mathrm{~mm})\end{array}$ & $\begin{array}{c}a \\
(\mathrm{~mm})\end{array}$ & $\begin{array}{c}\varepsilon_{F} \\
(\theta \rightarrow 90)\end{array}$ & $\alpha$ & $n$ \\
\hline \multirow{3}{*}{$T_{0} F(M)$} & No. 7 & 72.0 & 0.951 & 1.43 & 4.40 & 7.90 & 0.18 & \multirow{3}{*}{11,700} & \\
\hline & No. 8 & 65.5 & 0.910 & 1.50 & 3.37 & 6.52 & 0.23 & & \\
\hline & No. 9 & 62.0 & 0.883 & 1.52 & 2.85 & 5.43 & 0.28 & & \\
\hline \multirow{3}{*}{$\mathrm{T}_{26} \mathrm{~F}(\mathrm{M})$} & No. 10 & 70.0 & 0.939 & 1.47 & 4.30 & 5.25 & 0.28 & \multirow{3}{*}{\multicolumn{2}{|c|}{400}} \\
\hline & No. 11 & 66.0 & 0.913 & 1.49 & 3.26 & 4.81 & 0.31 & & \\
\hline & No. 12 & 62.5 & 0.887 & 1.48 & 2.84 & 4.48 & 0.33 & & \\
\hline
\end{tabular}

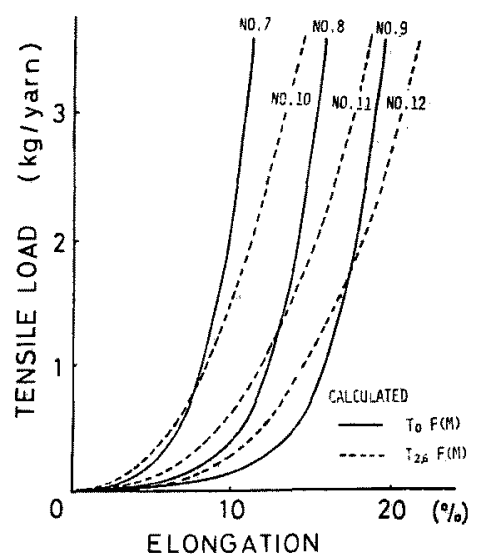

Fig. 12 The calculated curves in the initial regions of load-elongation.

$(-\ldots:$ twistless yarn fabric, - - - : : twist yarn fabric.)

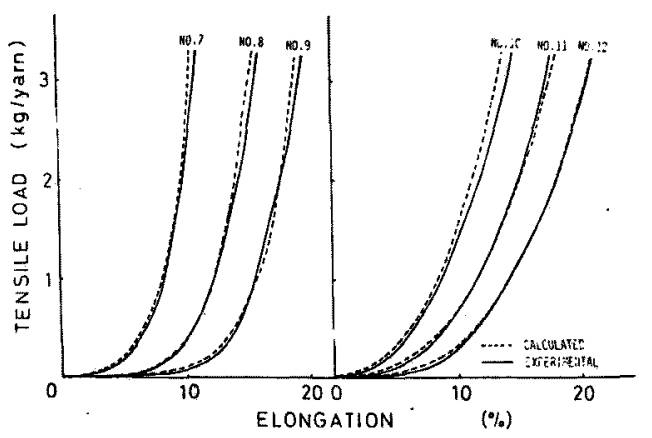

Fig. 13 Comparison between the calculated curves and the experimental curves in the initial regions of load-elongation.

No.7, No.8, No.9: twistless yarn fabric. (model)

No. 10, No.11, No. 12: twist y arn fabric. (model)

式のようにおき，因子 $\alpha, n の$ 值を実験曲線より求める。

$$
F_{Y}=\alpha \varepsilon_{Y}^{n}
$$

以上の無撚系織物と撚禾織物の測定結果より，(7)式 および(8) 式の各因子の值をまとめると表 2 のようにな る。表 2 值を(7)式に代入して, 各モデル織物の荷重 
一伸長曲線の初期の部分をかくと，图12のようになる。 実線は無然系織物で, 破線は撚系織物である。前述の実 験結果と同様の傾向がみられ，初期の伸度では無撚系織 物の方が然系傤物より荷重が小さく，5〜15\%の所でそ の㑯向が逆転している。この伸度に扔ける織物の系 1 本 あたりの荷重は，0.8〜 $1.6 \mathrm{~kg} /$ 糸であり，罒11よりこ の荷重に拈ける系の伸度は，5\%以下である。したがっ て、この現象は, 系強力よりもはとんど織物構造の变化 の違いに起因するものであると考えられる。つぎに，計 算值と実験值を比較すると図 13 のようになり、初期の 部分では大体よい一致がみら机る。

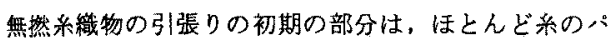
ッンク率の変化と系のクリンプ角の变化によって大き く左右される。引張り方向の系は，急激にパッング率 が增加し、そのため糸のクシンブ角が大きく変化し，し だいに円形化すると同時に同一平面上にのるようになる。 引張り方向に直交する系は，引張り方向の手の側圧によ り押し出され，クリンプ角が増加すると同時に，大きく 偏平化し，そのため引張り方向の系との接触面積および 側圧力が大きくなり，䄉維相互の滑脱を妨げる。伸度が 増すにつれて、この候向はさらに影著になり、引張り方 向の米が直線化し，内部綫維がびずみをうけるようにな ると，伸びに対する荷重が急激に增加するようになると 考えられる。

\section{4. 結言}

織物の初期伸長特性は，織物構造に関連した基本的な 問趣であり．実用的学閣的にも非常に重要な特性の1つ である。無撚系織物の初期の引張りにともなら織物中の 系の状態の変化を詳細に観察し，従来の撚綵織物と比較
检討した結果，つぎのことが明らかになった。

(1) 無撚系織物中の糸のパッキング率は，非常に低い (6〜8\%)が，引張りにともなって急激に增加する。 撚系織物では，そのような㑯向はあまり認められな い。

（2）引張りによる手の稨平化の程度は，無撚系の方が 然苏より大きい。

（3）引張りによる禾のクリンプ角の玟化は，無撚糸の 方が然系より大きく，低い伸度で糸の直線化が生ず る。

（4）無撚糸織物は，(1)－く3）のよ5に引張りの初期 に㧍ける織維の易動性が，撚系織物に比べて大きい ため, 两者の荷重 - 伸長曲線の初期の部分に差がみ られる。すなわち，低い伸度では，無撚系織物の方 が荷重が小さく、10\%前筏の伸度の所でその傾向が 逆転する。

以上のことは，無然系織物特有の非常にンフトである が，强力も十分にある性質と大いに開俰がある。

\section{文献}

1) R.D. Weels; Text. Res. J., 25, 481 (1955)

2) J.W. Powischili; Text. Res. J, 25, 486 (1955)

3) H.J. Selling; Twistless Yarns, MERROW (1971)

4) P.R. Load; Text. Res. J., 43, 96 (1973)

5) 渡辺, 黑崎, 近田; 緎学誌, 29, T313(1973)

6) F.T. Peirce; J. Text. Inst., 28, T45 (1937)

7) B. Olofsson; J. Text. Inst., 55, T541 (1964)

8) 白梏, 小口, 平山，清水; 繊学誌, 19, 171 (1963)

9) 青木; 織学誌, 4, 132 (1948)

10) 丹羽，川端, 菏合; 緎学誌, 19, T157 (1966) 20, T12 (1967) 20, T258 (1967) 20, T279 (1967) 20, T317 (1967) 